UDC 577.12:581.144.4:634.75

\title{
EFFECT OF CHITOSAN OF DIFFERENT ORIGINS ON THE CONTENTS OF PHENOLIC ANTIOXIDANTS IN FRAGARIA ANANASSA DUCH. LEAVES
}

\author{
O.V. SUBIN ${ }^{1}$, M.D. MELNYCHUK ${ }^{2}$, A.F. LIKHANOV ${ }^{3}$, V.G. SPYRYDONOV ${ }^{4}$ \\ ${ }^{1}$ National University of Life and Environmental Sciences of Ukraine \\ 15 Heroiv oborony St., , Kyiv, 03041, Ukraine \\ e-mail: subin.oleksandr@gmail.com \\ ${ }^{2}$ Agronomica LTD \\ 28 Lobanovskogo St., v. Chaiky, Kyiv-Sviatoshyn distr. Kyiv region, 08130, Ukraine \\ e-mail: melnychuk.maks@gmail.com \\ ${ }^{3}$ Institute for Evolutionary Ecology, National Academy of Sciences of Ukraine \\ 37 Acad. Lebedeva St., Kyiv, 03143, Ukraine \\ e-mail: likhanov.bio@gmail.com \\ ${ }^{4}$ Institute of Veterinary Medicine, National Academy of Agrarian Sciences of Ukraine \\ 30 Donetska St., Kyiv, 03151, Ukraine \\ e-mail: vlad.spyrydonov@gmail.com
}

Plants are subjected to an enormous number of biotic and abiotic environmental stresses during their life cycle. The responses to different stresses are very complex and include changes at the transcriptome, cellular, and physiological levels. The recognition of inductors and signaling molecules is one of the ways of inducting the plant's own defense mechanisms. The response reactions of Fragaria ananassa Duch. plants treated with chitosan of different origins and molecular weight were studied in our experiment. The plants exhibited highly reactive physiological responses. Chitosan with low molecular weight (ChI) caused intensification of phenylpropanoid synthesis, tannins formation and changed daily dynamics of secondary metabolism. Within twelve hours after treatment with $\mathrm{ChI}$ preparation, total phenolic and antioxidant amounts in leaves increased by 1.9 and 3.2 times respectively. Unlike ChI, the solution of high molecular weight chitosan (ChII) induced in leaves a sharp decrease of free and loosely-bound with cell walls phenolic compounds. We observed differences of plant primary response reactions to chitosan treatment. They depend on the origin of chitosan, its molecular weight and degree of deacetylation.

Keywords: Fragaria ananassa Duch., chitosan, leaves, phenols, elicitors, antioxidants.

Plants are subjected to enormously various biotic and abiotic environmental stresses during their life cycle. Their responses are very complex and include changes at the transcriptome, cellular, and physiological levels [3]. The recognition of inductors and signaling molecules is one of the ways to induce the plant's own defense mechanisms.

The inductors are chemical compounds of abiotic and biotic origin that stimulate stress responses in plants, leading to enhanced synthesis and accumulation of secondary metabolites or to new secondary metabolites [14]. Inductors can be generated by external factors (exogenous inductors) or as a result of physical and/or chemical destruction of plant cell walls (endogenous inductors) $[9,22]$. Following the perception of an inductor, signal transduc- 
tion pathways are activated generally causing the production of reactive oxygen species (ROS), phytoalexins biosynthesis, reinforcement of plant cell walls associated with phenylpropanoid compounds, callose deposition, defense enzyme synthesis and accumulation of pathogenesis-related (PR) proteins, a few of which possess antimicrobial properties [24, 25].

Phenylpropanoid compounds are one of the most important non-enzymatic systems of plant defense mechanisms. They not only indicate the plant stress responses to varying light or mineral nutrition levels, but are also key mediators of the plant resistance to pests $[12,26]$. Functions of the phenylpropanoid compounds in plant defense vary from preformed or induced physical and chemical barriers against infection to signaling molecules involved in local and systemic signaling for the induction of protective genes. Defensive functions are not limited to particular phenylpropanoid compounds, but are found in simple hydroxycinnamic acids and monolignols to more complex flavonoids, isoflavonoids, stilbenes, etc. [7].

The most known inductors are oligosaccharide moieties of fungal cell wall, including oligomers of chitin, chitosan and $\beta$-1.3-glucans, and oligogalacturonides, pectin fragments of plant cell wall $[15,21]$. Chitosan is the simplest linear polysaccharide composed of $\alpha, 1-4$ linked D-glucosamine $(\mathrm{GlcN})$ and $\mathrm{N}$-acetyl-D-glucosamine (GlcNAc) with different compositions of these two monomers $[6,10]$. The key parameters of chitosan biological activity are molecular weight and degree of deacetylation. As in many other polymers, the molecular weight of chitosan varies widely from 1-2 $\mathrm{kDa}$ in oligomers to several hundred $\mathrm{kDa}$ in high-molecular forms. The low molecular weight chitosan can penetrate cells and induce reprogramming of metabolic synthesis processes. The high molecular weight chitosan forms a film on the surface of infected plant tissues and prevents further spreading of pathogens.

Production of chitin and chitosan by fungal mycelium now attracts particular attention due to significant advantages. For example, while supplies of crustacean waste are limited by season and region of fishing industry, fungal mycelium can be obtained by convenient fermentation process without any geographical or seasonal limitations [27]. The amount of inorganic materials in fungal mycelia is lower compared with crustacean wastes, thus demineralization treatment is not required during the processing [23]. Crustacean chitin and chitosan may vary in the physico-chemical properties, while fungal chitin and chitosan are relatively consistent due to controlled conditions of fermentation process [17]. Apparently, fungal chitin and chitosan more effectively induce the plant immune response, and they are potentially more suitable for agricultural applications [11].

Chitin and chitosan can act as potent agents to elicit stronger plant defense reactions and inhibit the growth of several phytopathogenic fungi and bacteria [19]. It was found that chitosan effectively reduces the amount of polygalacturonases produced by Botrytis cinerea, which causes severe cytological damage to the hyphae invading bell pepper fruit [8]. Chitosan induced the synthesis of phytoalexin, a potent suppressor of fungal growth, in rice leaves [1]. The chitinase and peroxidase activity increased and growth of Botrytis cinerea was successfully inhibited when cucumber plants were sprayed with chitosan or chitin before Botrytis cinerea inoculation [4].

The aim of research was to study the specificity of response reactions in Fragaria ananassa Duch. plants after their treatment with chitosan of different molecular weight and origins. 


\section{Materials and methods}

Extraction of chitinous material. After treatments with alkali and acid, the chitinous material was obtained by the procedure adapted from Rane and Hoover [17] with our modification. The freeze-dried stalk powder was stirred with $1 \mathrm{M}$ $\mathrm{NaOH}$ (v:v 1:40) and refluxed at $95{ }^{\circ} \mathrm{C}$ for 30 min to extract proteins, alkalisoluble polysaccharides and small molecules (e.g., monosaccharides, phenolics, amino acids and salts). The sludge was centrifuged (12000 g, $20 \mathrm{~min}$, $22{ }^{\circ} \mathrm{C}$ ) and alkali-insoluble material (AIM) was washed two times with deionized water and $95 \%$ ethanol. After the final centrifugation, alkali insoluble residue was freeze-dried and ground to a fine powder. To obtain insoluble crude fungal chitin, AIM was soaked in $2 \%$ acetic acid (v:v 1:100) for 6 hours at $95{ }^{\circ} \mathrm{C}$. The acid-treated sludge was centrifuged $\left(12000 \mathrm{~g}, 20 \mathrm{~min}, 22{ }^{\circ} \mathrm{C}\right)$ and washed with deionized water and ethanol as described for AIM. Chitin, if present, remained as insoluble residue (crude chitin), and chitosan, if present, was extracted with aqueous acetic acid and precipitated from the supernatant after adjustment of $\mathrm{pH}$ to 10 .

Chitosan characterization. The first form of fungal chitosan (ChI) was obtained by the fermentative hydrolysis of basidiomycete sporocarps in our laboratory. The second form (ChII) was commercial crustacean chitosan.

Determination of degree of deacetylation. The extent of chitosan deacetylation was obtained by titration with $0.1 \mathrm{M} \mathrm{NaOH}$. First, the acetyl groups in chitosan were hydrolyzed with a strong alkali and the salt converted to acetate, than it was evaporated as an azeotrope with water and titrated. Thus the acetyl percentage was determined as follows:

$$
D A=2.03 \times \frac{\left(v_{2}-v_{1}\right)}{m+0.0042 \times\left(v_{2}-v_{1}\right)},
$$

where $m$ is sample mass; $v_{1}, v_{2}$ are volumes of $0.1 \mathrm{M} \mathrm{NaOH}$ titrating solution at the inflection points of the titration curve; 0.0042 is coefficient of difference of molecular masses of chitin and chitosan monomers; 2.03 is the molecular mass coefficient of the chitin monomer.

The degree of deacetylation for fungal chitosan $(\mathrm{ChI})$ is $80.39 \%$, for crustacean chitosan (ChII) it is $90.69 \%$.

Determination of kinematic viscosity. The capillary viscometer (VPZh-1) with $0.86 \mathrm{~mm}$ diameter was used to measure the viscosity. Chitosan solution was prepared in $1 \%$ acetic acid at $1 \%$ concentration on a moisture-free basis. Measurements were made thrice for each sample. Values were reported in centipoises units $(\mathrm{cP})$.

The liquid kinematic viscosity is determined by the formula:

$$
V=\frac{g}{9.807} \times T \times K
$$

where $\mathrm{K}$ is viscometer constant, $0.03169 ; V$ is kinematic viscosity of liquid, $\mathrm{mm}^{2} / \mathrm{s} ; T$ is time of liquid leakage, $\mathrm{s} ; g$ is the acceleration of free fall at the place of measurement, $9.81 \mathrm{~m} / \mathrm{s}^{2}$.

For fungal chitosan $(\mathrm{ChI})$ the value was $111 \mathrm{cP}$ indicating low molecular weight chitosan. For crustacean chitosan (ChII) the value was $3003 \mathrm{cP}$ indicating high molecular weight chitosan.

Plant material and treatment with chitosan solutions. The Fragaria ananassa Duch. plants (variety Alina) were used in experiments. Microclonally propagated plants were adapted to in vivo conditions. After adaptation, the plants 
were growing on a special growing medium in culture laboratory with constant temperature and photoperiod.

The $0.4 \%$ chitosan solutions with different molecular weights were dissolved in $0.05 \mathrm{~N}$ hydrochloric acid, then $\mathrm{pH}$ was adjusted to 5.6 with $\mathrm{NaOH}$. Distilled water was used as control.

The leaf samples were collected before spraying (controls) and after one, twelve, 24 and 48 hours. Samples were exhaustively extracted with methanol in the ratio of $1: 10$.

Total phenol analysis. The total phenolic contents of treated leaves were measured using the Folin-Ciocalteu method in modification by Singleton and Rossi [20]. $50 \mu \mathrm{l}$ of sample were diluted in $450 \mu \mathrm{l}$ of methanol, and then mixed with $2.5 \mathrm{ml}$ of Folin-Ciocalteu reagent and $2.0 \mathrm{ml}$ of $7 \%$ sodium carbonate. After that the solution was incubated at room temperature for two hours. The absorbance of solution was spectrophotometrically measured at $765 \mathrm{~nm}$.

Determination of free radical scavenging activity. Free radical scavenging activity was determined by modified Blois method [5]. Stable 1.1-diphenyl-2picrylhydrazyl radical (DPPH) was used for determination of free radicalscavenging activity of plant extracts. $400 \mu \mathrm{l}$ of $0.2 \mathrm{mM} \mathrm{DPPH}$ ethanol solution were added to $50 \mu \mathrm{l}$ of plants extracts and $350 \mu \mathrm{l}$ of methanol. After $30 \mathrm{~min}$ the absorbance was measured at $517 \mathrm{~nm}$ and converted into the percentage of antioxidant activity (AA) using the following formula:

$$
\mathrm{AA} \%=100-\left\{\left[\left(\mathrm{Abs}_{\text {sample }}-\mathrm{Abs}_{\text {blank }}\right) \times 100\right] / \mathrm{Abs}_{\text {control }}\right\} \text {. }
$$

HPLC analysis. The samples were analyzed with HPLC system (Agilent 1260 series, Waldbronn, Germany) equipped with diode array absorbance detector (DAD). Zorbax SB-C-18 column, $250 \times 4.6 \mathrm{~mm}, 5 \mu \mathrm{m}$ of i.d. (Agilent, USA) was used. The mobile phase consisted of acetonitrile (A) and diluted phosphoric acid (0.5:99.5 v/v) (B) at a flow rate of $1 \mathrm{ml} / \mathrm{min}$. Phenolic compounds were separated in the following gradient of $\mathrm{A}$ in $\mathrm{B}(\% \mathrm{v} / \mathrm{v}): 0-5$ $\min , 15 \% \mathrm{~A} ; 5-25 \mathrm{~min}, 15-35 \% \mathrm{~A} ; 25-35 \mathrm{~min}, 35 \% \mathrm{~A}$. UV spectra were recorded between 200 and $450 \mathrm{~nm}$, and the UV trace was measured at $254 \mathrm{~nm}$. The column was maintained at $25{ }^{\circ} \mathrm{C}$.

The data were statistically processed in Statistica 7.0 software (USA).

\section{Results and discussion}

Fragaria ananassa Duch. plants are characterized by accumulation of hydrolysable tannins (HHDP-glucose, agrimoniin and 1-O-galloylglucose), kaempferol and quercetin glycosides in leaves, which perform defense, regulatory and redox functions.

High-performance liquid chromatography indicated gallo- and ellagitannins as the most dynamic group of polyphenols in Fragaria ananassa Duch. (Fig. 1).

After treatment of Fragaria ananassa Duch. plants with chitosan of different origins and molecular weight, we studied the plants' response reactions. Content of phenols, catechins, flavonoids, and total antioxidant potential of secondary metabolites were used as the main indicators.

The dynamic of phenolic compounds amount in leaves was observed after a single treatment with $0.4 \%$ chitosan solutions with different molecular weights (ChI and ChII). Control plants were treated with water. In a control group of plants the indices of phenolic compounds amount decreased a little within the first hours after treatment. 


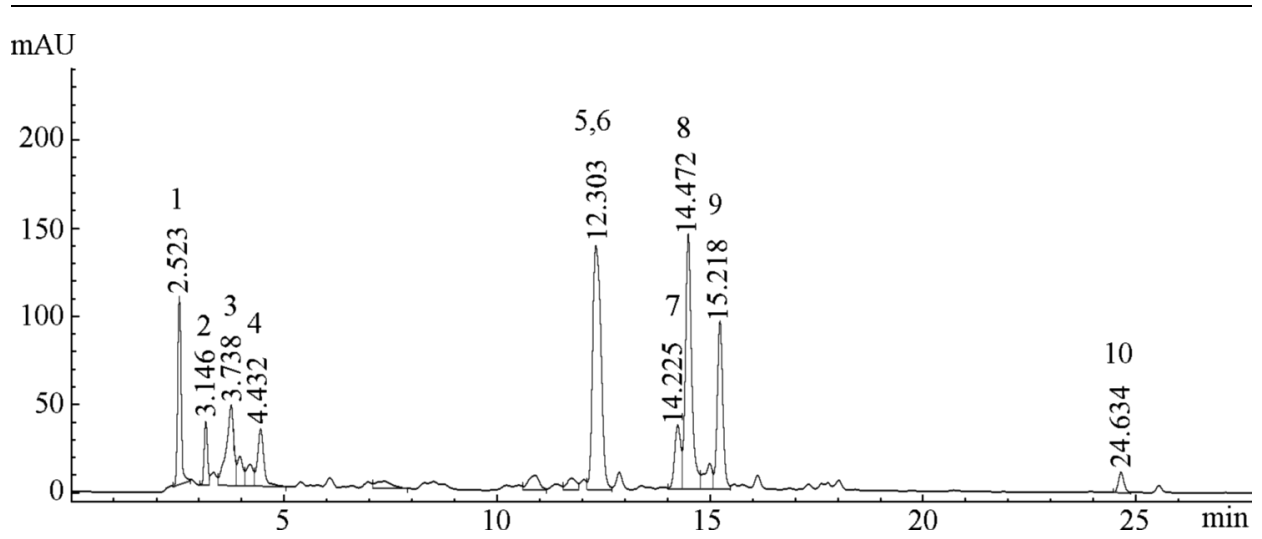

Fig. 1. HPLC profile of Fragaria ananassa Duch. leaves:

1 - HHDP-glucose; 2 - galloquinic acid; 3 - ellagitannin; 4 - ellagitannin; 5 - ellagic acid pentoside; 6 kaempferol hexose glucuronide; 7 - ellagitannin; $8-$ ellagic acid; $9-$ flavonol glycoside; $10-$ tiliroside

Probably, this effect can be related to the decrease of temperature and transpiration rate after water treatment of aboveground plant part. Furthermore, decrease of phenolic compounds amount was a result of natural circadian rhythms, as soon as the treatment was performed during the late evening. Daily variations of total phenols' amount can be related to their natural polymerization and integration into the cell walls as lignin and suberin.

The high reactivity of response physiological reactions was shown in chitosan-treated Fragaria ananassa Duch. plants. The phenylpropanoid synthesis, tannins formation and elimination of daily dynamics of secondary metabolism were intensified by the low molecular weight chitosan (ChI). During early hours after treatment we observed the first significant changes of phenolic compounds amount in leaves (Fig. 2.). Within twelve hours after treatment with ChI preparation, total phenolic and antioxidant amounts in leaves increased by 1.9 and 3.2 times respectively. Such intense response reaction implies a high biological activity of low molecular weight chitosan.

Dynamics of phenolic and antioxidant amounts in leaves is described by the logistic function:

$$
f(y)=y_{0}+a \times \exp \left(-\frac{1}{2 x} \times\left(\frac{\ln \frac{x}{x_{0}}}{b}\right)^{2}\right) .
$$

This equation exactifies the natural dynamics and response physiological reactions of plants.

Unlike ChI, the solution of high molecular weight chitosan (ChII) induced a sharp decrease of free and loosely-bound with cell walls phenolic compounds in leaves (Fig. 3). The decrease of free phenolics and antioxidants in leaves during the first hour after treatment with ChII was linear (equations 2 and 3 , respectively).

$$
\begin{aligned}
& y=100-47.2590 x ; \\
& y=100-37.2661 x .
\end{aligned}
$$

Further dynamics was described by lognormal addiction (equation 1), which is typical to ChI-treated plants.

In our experiment, the plant leaves were not subjected to traumatic stress. Therefore, vacuole membranes were not destroyed and phenolic compounds (conjugates of chlorogenic and cinnamic acids) were not altered in an inter- 


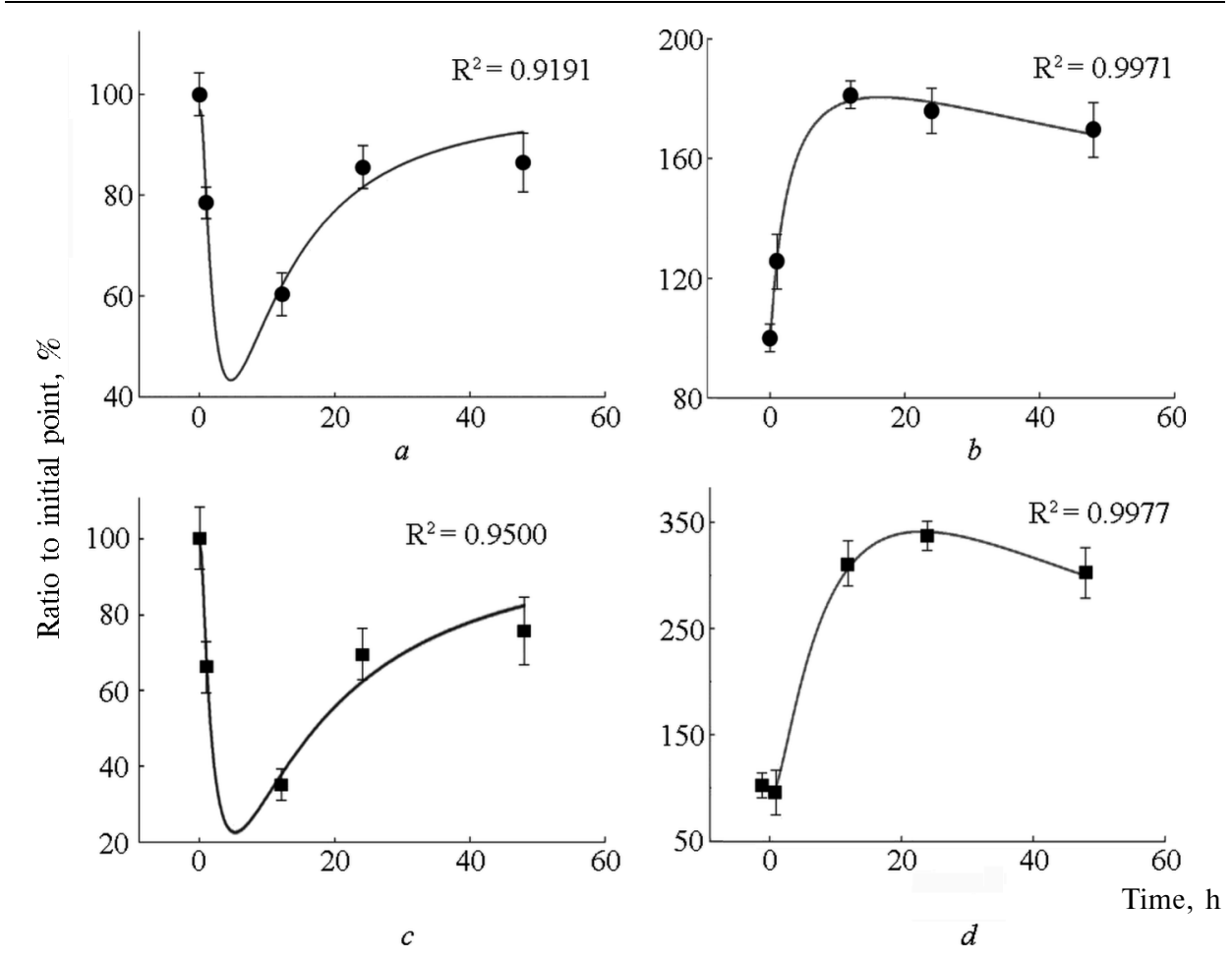

Fig. 2. Dynamic of phenols $(a, b)$ and antioxidants $(c, d)$ content in Fragaria ananassa Duch. leaves after treatments:

$a, c$ - water (control); $b, d$ - low molecular weight chitosan (ChI). Initial point (before treatment) is equal $100 \%$

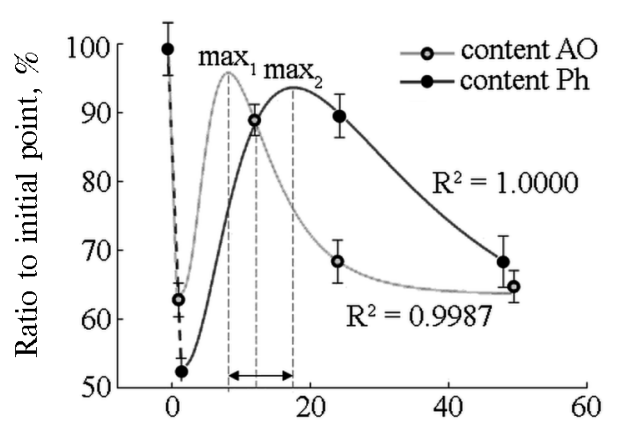

$a$

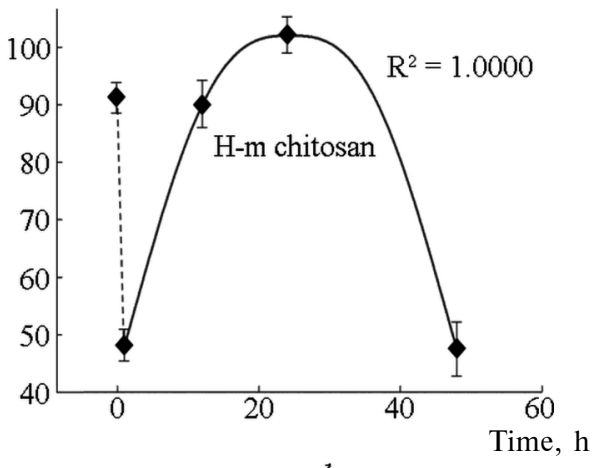

$b$

Fig. 3. Synchronized content of phenolic compounds, antioxidants $(a)$ and catechins $(b)$ in Fragaria ananassa Duch. leaves after high molecular weight chitosan (ChII) treatment:

$\mathrm{Ph}-$ content of phenolic compound (ratio to initial point, \%); AO - antioxidants (ratio to initial point, \%)

cellular space. Phenolic transformation (oxidation and polymerization) induced by chitosan mainly affected ellagitannins and catechins.

Due to experimental conditions, the polymerization of catechin (flavan3-ols) to condensed tannins (proanthocyanidins) occurred mainly in vacuoles and other cell compartments.

The dynamics of catechin amount was fully consistent with total phenols amount within the first 24 hours after treatment with high molecular weight chitosan. Within the first hour after treatment the amount of catechins and 
proanthocyanidins decreased almost in half compared with control. Within the next twelve hours this amount almost fully restored. After 24 hours this index slightly increased to the control level and decreased again.

Thus, the response reaction of plant organism includes several successive stages:

1. Linear decrease of catechin concentration;

2. Lognormal increase with repeated decreasing of this index.

The kinetics of defense initiation in plants is an important indicator of susceptibility to pathogens. The survival strategy of plant organism is determined by the speed of response reaction. The defense mechanisms are not limited by primary reactions foremost. They induce a wide range of biochemical and structural changes in cells. The most rapid response to stress factor or elicitor action is phenol oxidation and phytoalexins formation. Plant tannins are oxidized by polyphenol oxidases and peroxidases at acidic and neutral $\mathrm{pH}$ [2]. At the same time, as noted by Salminen et al. [18], the structural features of tannins play an important role in the oxidation by polyphenol oxidases, because certain groups are oxidized at different $\mathrm{pH}$ values.

Oxidation processes precede the formation of proteinases, hydrolases and proline-rich proteins. Structural changes of cell wall can be observed within the first hours after external influence. These changes are attributed to the callose forming on cell wall surface. Lignification processes occur within 12-24 hours after the plant was treated with inductor.

In our experiment the response reactions of Fragaria ananassa Duch. plants were typical for induced immunity during the first hour after treatment with chitosan solutions.

Sharp decrease of phenol amount in response to ChII-solution treatment can be caused by the decreased reducing ability of Folin-Ciocalteu reagent due to the intense oxidation. Furthermore, plants are capable of deep catabolic conversion of phenolic compounds to products of primary metabolism [16].

Phenols increase the plant ability to bind potential pathogen proteins and prevent adverse effects upon oxidation to quinones. It is more difficult to explain the influence of ChI-solution on plants within the first hour after treatment. Activation of phenylpropanoid pathway and tannins accumulation are prolonged metabolic processes. The significant increase of total phenols and antioxidant activity as fast plant response reaction after $\mathrm{ChI}$ treatment can be caused by depolymerization of tannins.

This defense mechanism was described by Moilanen et al. [13], but the phenomenon has not yet received enough scientific attention. Hydrolysis of tannins results in relatively few phenolic compounds (e.g. gallic acid, ellagic acid, valoneic acid dilactone). They can act in completely different ways than their larger tannin precursors.

In our experiment the particularity of plant defense responses to chitosan with different molecular weight was more pronounced within the first 12 hours after treatment. The dynamics of phenolic content in Fragaria ananassa Duch. cells leveled off in the next 36 hours. Thus, we observed differences of plant primary response reactions to chitosan treatment. They depend on the origin of chitosan, its molecular weight and degree of deacetylation. The low molecular weight chitosan quickly interacts with tissue and cellular barriers. It penetrates into a protoplast and causes a sharp increase of total phenols amount and antioxidant activity in tissues. The sharp increase of total phenols amount and antioxidant activity in response to low molecular weight chitosan of fungal origin can be considered as general plant mobilization against potential 
pathogens. The strength and speed of response reaction implies that the corresponding system is prepared to perceive molecular trigger (inductor) and to initiate the response physiological reactions in this variety of Fragaria ananas$s a$ Duch. Further research in this direction is perspective for preventing contamination of Fragaria ananassa Duch. plants by pathogenic organisms and viruses and their spreading.

The fundamental difference of plant reactions to high molecular weight chitosan indicates an entirely different system of the stimulus perception.

The rapid decrease of phenols can be related to the strategy of tissue isolation and oxidative burst which neutralize the potential threat. The oxidation of phenols, additional lignification and suberinization of cell walls are the results. The plant induced immunity is not strictly specific. With this fact, only after the onset of disease symptoms, the similar transformations can be effective on the cellular level.

Nonspecific activation of signal systems and oxidative burst can localize the distribution of pathogen with further mobilization of other plant defense mechanisms.

\section{Conclusions}

In our study we observed differences of plant primary response reactions to chitosan treatment. The differences depend on the origin of chitosan, its molecular weight and degree of deacetylation. The low molecular weight chitosan quickly interacts with tissue and cellular barriers. It penetrates into a protoplast and causes sharp increase of total phenols amount and antioxidant activity in tissues. In response to low molecular weight chitosan of fungal origin, sharp increase of total phenols amount and antioxidant activity can be considered as general plant mobilization against potential pathogens. The significant difference of plants reaction to high molecular weight chitosan indicates an entirely different system of the response reactions. The rapid decrease of phenols amount can be related to the strategy of tissue isolation and oxidative burst which neutralize the potential threat. The oxidation of phenols, additional lignification and suberinization of cell walls are the results of this reaction. Nonspecific activation of signal systems and oxidative burst can localize the distribution of pathogen with further mobilization of other plant defense mechanisms.

\section{REFERENCES}

1. Agrawal, G., Rakwal, R., Tamogami, S., Yonekura, M., Kubo, A. \& Saji, H. (2002). Chitosan activates defense/stress response(s) in the leaves of Oryza sativa seedlings. Plant Physiology and Biochemistry, 40(12), pp. 1061-1069. doi: http://dx.doi.org/10.1016/s0981-9428(02)01471-7.

2. Appel, H. (1993). Phenolics in ecological interactions: The importance of oxidation. J. Chemical Ecol., 19(7), pp. 1521-1552. doi: http://dx.doi.org/10.1007/bf00984895.

3. Atkinson, N. \& Urwin, P. (2012). The interaction of plant biotic and abiotic stresses: from genes to the field. J. Exp. Bot., 63(10), pp. 3523-3543. doi: http://dx.doi.org/ $10.1093 / \mathrm{jxb} / \mathrm{ers} 100$.

4. Ben-Shalom, N., Árdi, R., Pinto, R., Aki, C. \& Fallik, E. (2003). Controlling gray mould caused by Botrytis cinerea in cucumber plants by means of chitosan. Crop Protection, 22(2), 285-290. doi: http://dx.doi.org/10.1016/s0261-2194(02)00149-7.

5. Brand-Williams, W., Cuvelier, M. \& Berset, C. (1995). Use of a free radical method to evaluate antioxidant activity. LWT - Food Sci. Technol., 28(1), pp. 25-30. doi: http://dx.doi.org/10.1016/s0023-6438(95)80008-5.

6. Brine, C., Sandford, P. \& Zikakis, J. (1992). Advances in chitin and chitosan. Elsevier Applied Science. 
7. Dixon, R., Achnine, L., Kota, P., Liu, C., Reddy, M. \& Wang, L. (2002). The phenylpropanoid pathway and plant defence - a genomics perspective. Mol. Plant Pathol., 3(5), pp. 371-390. doi: http://dx.doi.org/10.1046/j.1364-3703.2002.00131.x.

8. El Ghaouth, A., Arul, J., Wilson, C. \& Benhamou, N. (1997). Biochemical and cytochemical aspects of the interactions of chitosan and Botrytis cinerea in bell pepper fruit. Postharvest Biol. Technol., 12(2), pp. 183-194. doi: http://dx.doi.org/10.1016/s0925-5214(97)00056-2.

9. Garcia-Garrido, J. \& Ocampo, J. (2002). Regulation of the plant defence response in arbuscular mycorrhizal symbiosis. J. Exp. Bot., 53(373), pp. 1377-1386. doi: http://dx.doi.org/10.1093/jxb/53.373.1377.

10. Katiyar, D., Hemantaranjan, A., Singh, B. \& Bhanu, A. (2014). A future perspective in crop protection: Chitosan and its Oligosaccharides. Advances In Plants \& Agriculture Research, 1, pp. $1-8$

11. Knorr, D., Beaumont, M. \& Pandya, Y. (1989). Potential of acid soluble and water soluble chitosan in biotechnology. In G. Skjak-Braek, T. Anthonsen \& P. Sanford (Eds) Chitin and chitosan (pp. 101-118). London, New York: Elsevier Appl. Sci.

12. La Camera, S., Gouzerh, G., Dhondt, S., Hoffmann, L., Fritig, B., Legrand, M. \& Heitz, T. (2004). Metabolic reprogramming in plant innate immunity: the contributions of phenylpropanoid and oxylipin pathways. Immunol. Reviews, 198(1), pp. 267-284. doi: http://dx.doi.org/ 10.1111/j.0105-2896.2004.0129.x.

13. Moilanen, J., Sinkkonen, J. \& Salminen, J. (2013). Characterization of bioactive plant ellagitannins by chromatographic, spectroscopic and mass spectrometric methods. Chemoecology, 23(3), pp. 165-179. doi: http://dx.doi.org/10.1007/s00049-013-0132-3.

14. Naik, P. \& Al-Khayri, J. (2016). Abiotic and biotic elicitors - role in secondary metabolites production through in vitro culture of medicinal plants. In A. Shanker \& C. Shanker (Eds) Abiotic and Biotic Stress in Plants - Recent Advances and Future Perspectives (pp. 247277). InTech. doi: http://dx.doi.org/10.5772/61442.

15. Ozeretskovskaya, O., Vasyukova, N. \& Zinovieva, S. (2002). Chitosan as an elicitor of induced plant resistance. In G. Skryabin, G. Vikhoreva \& V. Varlamov (Eds) Chitin and chitosan production, propeties and usage (pp. 280-360). Moscow: Nauka.

16. Prasad, S. \& Ellis, B. (1978). In vivo characterization of catechol ring-cleavage in cell cultures of Glycine max. Phytochemistry, 17(2), pp. 187-190. doi: http://dx.doi.org/10.1016/s00319422(00)94143-8.

17. Rane, K. \& Hoover, D. (1993). Production of chitosan by fungi. Food Biotechnol., 7(1), pp. 11-33. doi: http://dx.doi.org/10.1080/08905439309549843.

18. Salminen, J. \& Karonen, M. (2011). Chemical ecology of tannins and other phenolics: we need a change in approach. Functional Ecol., 25(2), pp. 325-338. doi: http://dx.doi.org/10.1111/ j.1365-2435.2010.01826.x.

19. Shibuya, N. \& Minami, E. (2001). Oligosaccharide signalling for defence responses in plant. Physiological Mol. Plant Pathol., 59(5), pp. 223-233. doi: http://dx.doi.org/10.1006/pmpp.2001.0364.

20. Singleton, V. \& Rossi, J. (1965). Colorimetry of total phenolics with phosphomolybdicphoungstic acid reagent. Am. J. Enol. Vitic., 16, pp. 144-158.

21. Sokolov, Y. (2014). Elicitors and their application. Proceedings of The National Academy of Sciences of Belarus: Chemical Series, 4, pp. 109-118.

22. Somssich, I. \& Hahlbrock, K. (1998). Pathogen defence in plants - a paradigm of biological complexity. Trends In Plant Science, 3(3), pp. 86-90. doi: http://dx.doi.org/10.1016/s13601385(98)01199-6.

23. Teng, W., Khor, E., Tan, T., Lim, L. \& Tan, S. (2001). Concurrent production of chitin from shrimp shells and fungi. Carbohydrate Research, 332(3), pp. 305-316. doi: http://dx.doi.org/10.1016/ s0008-6215(01)00084-2.

24. Thakur, M. \& Sohal, B. (2013). Role of elicitors in inducing resistance in plants against pathogen infection: a review. ISRN Biochemistry, 2013, pp. 1-10. doi: http://dx.doi.org/10.1155/2013/ 762412.

25. Van Loon, L. \& Van Strien, E. (1999). The families of pathogenesis-related proteins, their activities, and comparative analysis of PR-1 type proteins. Physiol. Mol. Plant Pathol., 55(2), pp. 85-97. doi: http://dx.doi.org/10.1006/pmpp.1999.0213.

26. Vogt, T. (2010). Phenylpropanoid biosynthesis. Mol. Plant, 3(1), pp. 2-20. doi: http://dx.doi.org/ 10.1093/mp/ssp106.

27. White, S., Farina, P. \& Fulton, I. (1979). Production and isolation of chitosan from Mucor rouxii. Appl. Environ. Microbiol., 38(2), pp. 323-328.

Received 27.03.2018 


\title{
ВПЛИВ РІЗНИХ ФОРМ ХІТОЗАНУ НА ВМІСТ ФЕНОЛЬНИХ АНТИОКСИДАНТІВ У ЛИСТКАХ FRAGARIA ANANASSA DUCH.
}

\author{
О.В. Субін ${ }^{1}$, М.Д. Мельничук ${ }^{2}$, А.Ф. Ліханов ${ }^{3}$, В.Г. Спиридонов ${ }^{4}$ \\ 'Національний університет біоресурсів і природокористування України, Київ \\ ${ }^{2}$ ТОВ «Агрономіка», с. Чайки, Києво-Святошинський р-н, Київська обл. \\ ${ }^{3}$ Інститут еволюційної екології Національної академії наук України, Київ \\ ${ }^{4}$ Інститут ветеринарної медицини Національної академії аграрних наук України, Київ
}

Протягом життєвого циклу рослини піддаються величезній кількості біотичних та абіотичних стресів. Відповіді на різні стреси дуже складні і включають зміни на транскриптомному, клітинному та фізіологічному рівнях. Розпізнавання індукторів і сигнальних молекул $є$ одним з елементів роботи власних захисних механізмів. У нашому експерименті досліджено реакції-відповіді Fragaria ananassa Duch. після обробки розчинами хітозану різного походження, молекулярної маси та ступеня деацетилювання. Низькомолекулярний хітозан (ChI) викликав інтенсифікацію фенілпропаноїдного синтезу, утворення танінів і змінював добову динаміку вторинного метаболізму. Виявлено, шо в перші 12 годин після обробки рослин розчином $\mathrm{ChI}$ загальний рівень фенолів й антиоксидантів зростав у 1,9 та 3,2 раза відповідно. На відміну від низькомолекулярного хітозану розчин високомолекулярного полімеру (ChII) спричинював у листках різке зниження вмісту вільних і слабозв'язаних з клітинними стінками фенольних сполук. Встановлено відмінності в первинних реакціях рослин на хітозан, які залежали від джерела отримання біополімеру, його молекулярної маси і ступеня деацетилювання.

Ключові слова: Fragaria ananassa Duch., хітозан, листки, феноли, еліситори, антиоксиданти.

\section{ВЛИЯНИЕ РАЗНЫХ ФОРМ ХИТОЗАНА НА СОДЕРЖАНИЕ ФЕНОЛЬНЫХ АНТИОКСИДАНТОВ В ЛИСТЬЯХ FRAGARIA ANANASSA DUCH.}

\author{
А.В. Субин ${ }^{1}$ М.Д. Мельничук², А.Ф. Лиханов ${ }^{3}$, В.Г. Спиридонов ${ }^{4}$ \\ ${ }^{1}$ Национальный университет биоресурсов и природопользования Украины, Киев \\ ${ }^{2} \mathrm{OOO}$ «Агрономика», с. Чайки, Киево-Святошинский р-н., Киевская обл. \\ ${ }^{3}$ Институт эволюционной экологии Национальной академии наук Украины, Киев \\ ${ }^{4}$ Институт ветеринарной медицины Национальной академии аграрных наук Украины, \\ Киев
}

В течение жизненного цикла растения подвергаются огромному количеству биотических и абиотических стрессов. Ответы на различные стрессы очень сложны и включают изменения на транскриптомном, клеточном и физиологическом уровнях. Распознавание индукторов и сигнальных молекул является одним из элементов работы собственных защитных механизмов. В нашем эксперименте исследованы ответные реакции Fragaria ananassa Duch. после обработки растворами хитозана различного происхождения, молекулярной массы и степени деацетилирования. Низкомолекулярный хитозан (ChI) вызывал интенсификацию фенилпропаноидного синтеза, образования таннинов и изменял суточную динамику вторичного метаболизма. Обнаружено, что в первые 12 часов после обработки растений раствором ChI общий уровень фенолов и антиоксидантов возрастал в 1,9 и 3,2 раза соответственно. В отличие от низкомолекулярного хитозана раствор высокомолекулярного полимера (ChII) вызывал в листьях резкое снижение содержания свободных и слабосвязанных с клеточными стенками фенольных соединений. Установлены различия в первичных реакциях растений на хитозан, которые зависели от источника получения биополимера, его молекулярной массы и степени деацетилирования.

Ключевые слова: Fragaria ananassa Duch., хитозан, листья, фенолы, элиситоры, антиоксиданты. 